\title{
Review of Treatment Options for Irritable Bowel Syndrome with Constipation and Chronic Idiopathic Constipation
}

\author{
Sarah Patel ${ }^{1,2}$ \\ Bethany Doerfler ${ }^{3}$ \\ Katerine Boutros ${ }^{4}$ \\ Samson $\mathrm{Ng}^{4}$ \\ Machelle Manuel $^{5}$ \\ Elayne DeSimone ${ }^{6}$
}

'Department of Gastroenterology and Hepatology, Weill Cornell Medicine, New York, NY, USA; ${ }^{2}$ Rutgers University, Piscataway, NJ, USA; ${ }^{3}$ Division of Gastroenterology, Northwestern Medicine, Chicago, IL, USA; ${ }^{4}$ Global Medical Affairs Gastroenterology \& Hepatology, AbbVie Inc, Madison, NJ, USA; ${ }^{5}$ ronwood Pharmaceuticals, Inc, Cambridge, MA, USA; ${ }^{6}$ Community Volunteers in Medicine, West Chester, PA, USA

Correspondence: Sarah Patel Department of Gastroenterology and Hepatology, Weill Cornell Medicine, New York, NY, USA

Tel + I-(908)-642-6979

Email soneil86@gmail.com

\begin{abstract}
Irritable bowel syndrome with constipation (IBS-C) and chronic idiopathic constipation (CIC) are two common disorders of gut-brain interaction. Affected patients often first present to their primary care providers seeking care for symptoms of constipation, abdominal pain, and bloating, which have a significant impact on their health-related quality of life. These patients often require extensive counseling and reassurance, and knowledge of reliable diagnostic criteria and treatment options is imperative to managing their conditions. Family medicine practitioners, including nurse practitioners and physician assistants, are uniquely qualified to provide a diagnosis and safe, effective management of these disorders. This article reviews the latest evidence and provides practical advice related to diagnosis and management of IBS-C and CIC.
\end{abstract}

Keywords: advanced practice providers, chronic idiopathic constipation, constipation, irritable bowel syndrome, nurse practitioners, physician assistants

\section{Background}

Irritable bowel syndrome with constipation (IBS-C) and chronic idiopathic constipation (CIC), sometimes referred to as functional constipation, are two symptom-based disorders of gut-brain interaction defined by the Rome diagnostic criteria. ${ }^{1-3}$ Irritable bowel syndrome (IBS) is defined by the presence of recurrent abdominal pain associated with a change in defecation and is subtyped by the predominant stool pattern (ie, constipation for IBS-C). CIC is defined by the frequency of specific bowel symptoms, such as straining and incomplete evacuation, which can be accompanied by abdominal symptoms such as pain or bloating, in patients who do not meet the criteria for IBS. Abdominal pain is considered the hallmark symptom of IBS-C but is not necessarily the predominant symptom in CIC. ${ }^{1,2}$ Nonetheless, symptom overlap does occur between these two disorders, and IBS-C and CIC share symptoms of infrequent bowel movements (BMs), straining during defecation, hard and/or lumpy stools, and the sensation of incomplete evacuation.

Although these two disorders are considered distinct in terms of diagnostic criteria, recent studies have demonstrated that they may exist along a spectrum of severity. ${ }^{1,3}$ One study of patients with CIC with and without abdominal symptoms found that patient-reported disease severity tracked closely with the presence of abdominal symptoms and suggested that abdominal symptoms could provide a measurement of disease severity along a continuum. ${ }^{2}$ Therefore, in clinical 
practice, there may be little separation between the symptoms of the two disorders, and patients may migrate from one diagnosis to the other over the course of their disorder. $^{2,4}$

Patients with IBS-C and CIC often seek medical care owing to difficulty with BMs or abdominal pain and bloating $^{5}$ and will often first seek medical care from their primary care providers, who may include nurse practitioners (NPs) and physician assistants (PAs). ${ }^{6}$ NPs and PAs need to be familiar with the latest evidence on the recognition and diagnosis of IBS-C and CIC in order to provide safe and effective healthcare. ${ }^{6}$ In this review, we present current approaches to the differential diagnosis and multifaceted management of both IBS-C and CIC.

The prevalence of constipation in the general population ranges from $2 \%$ to $27 \%$, with the variability arising from differing definitions and populations. ${ }^{7-9}$ In the US, the prevalence of IBS-C is $4.3-5.2 \%$ of patients with IBS, ${ }^{10-12}$ while the mean prevalence of $\mathrm{CIC}$ is $12.0-19.0 \%{ }^{1,8,13}$ IBS most commonly presents between the ages of 25 and 54 years, ${ }^{12,14}$ and the overall prevalence is $67 \%$ higher in women internationally. ${ }^{15}$ Risk factors for CIC include female sex, reduced caloric intake, and increasing age. ${ }^{1}$

IBS-C and CIC are both associated with recurrent, bothersome symptoms that profoundly reduce patients' quality of life (QoL) $)^{16,17}$ and productivity, and increase the number of missed days of work or school. ${ }^{2,18}$ IBS-C and CIC also pose a significant financial burden to patients and healthcare systems. In the US, the reported mean annual all-cause healthcare cost associated with IBS-C in 2010 was $\$ 11,182$ per patient, with over half $(53.7 \%)$ of costs attributable to outpatient services, including physician office visits and other outpatient services (13.1\% and $40.6 \%$, respectively). ${ }^{10}$ In 2002 , the direct cost per patient ranged from $\$ 1600$ to $\$ 7500$ per year for IBS and from $\$ 1900$ to $\$ 7500$ per year for CIC. ${ }^{16}$

\section{Making a Diagnosis \\ Role of NPs and PAs in Recognizing IBS-C and CIC}

Many patients with IBS-C or CIC suffer for years before discussing their symptoms with a healthcare practitioner. ${ }^{19}$ Patients may feel embarrassed about their disorder; therefore, establishing effective communication is important. ${ }^{19,20}$ Patient-centered interviewing focused on identifying how the patient experiences the disorder in their everyday life encourages patients to lead the discussion, and may ultimately increase patient satisfaction and adherence. $^{21}$

Most often, NPs and PAs are the first healthcare providers to encounter patients with IBS-C or CIC, often diagnosing and managing them in the primary care setting. Owing to the time required, NPs and PAs are well positioned to care for patients with IBS-C or CIC, particularly those who require extensive counseling, education, and/or reassurance (ie, frequent office visits or phone calls). In addition, patients may speak first to an NP or PA regarding constipation or abdominal symptoms prior to seeing a gastroenterologist. Therefore, it is important for NPs and PAs to recognize these disorders and make confident diagnoses in the primary care setting in order to prevent unnecessary referrals.

\section{Differential Diagnosis of IBS-C and CIC}

The Rome IV diagnostic criteria distinguish disorders of gut-brain interaction based on clinical symptoms, but there is some overlap between the disorders (Figure 1). While abdominal pain is the hallmark symptom of all IBS subtypes, patients with CIC primarily experience constipation, but may also secondarily experience abdominal pain as well as abdominal bloating and distension.

A detailed patient assessment is critical to determine a diagnosis and the appropriate treatment for each patient, depending on where their condition falls along the spectrum (Figure 2). A thorough clinical history and physical examination are useful to reassure the patient and exclude organic

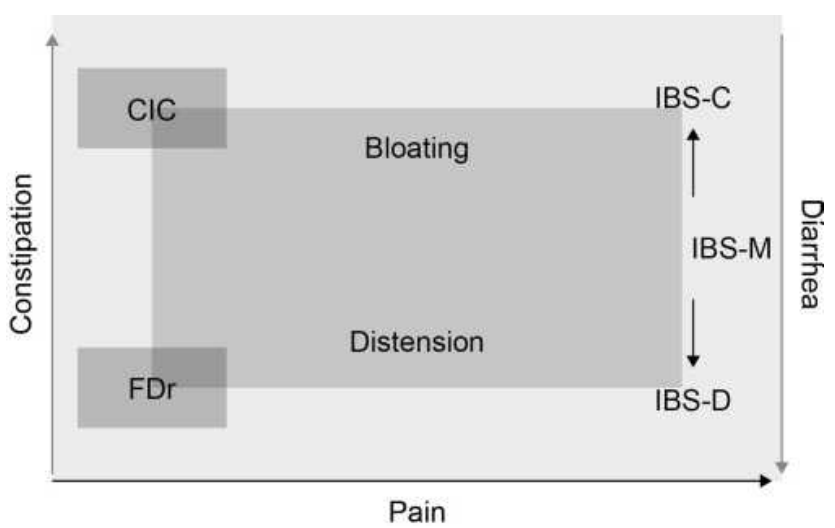

Figure I Disorders of gut-brain interaction exist on a continuum. Note: () 2016 Rome Foundation, Inc. All Rights Reserved. Modified from Rome Foundation's Rome IV Functional Gastrointestinal Disorders, Disorders of the GutBrain Interaction - Volume II - Page $970 .^{56}$

Abbreviations: CIC, chronic idiopathic constipation; FDr, functional diarrhea; IBS$C$, irritable bowel syndrome with constipation; IBS-D, irritable bowel syndrome with diarrhea; IBS-M, irritable bowel syndrome with mixed bowel habits. 


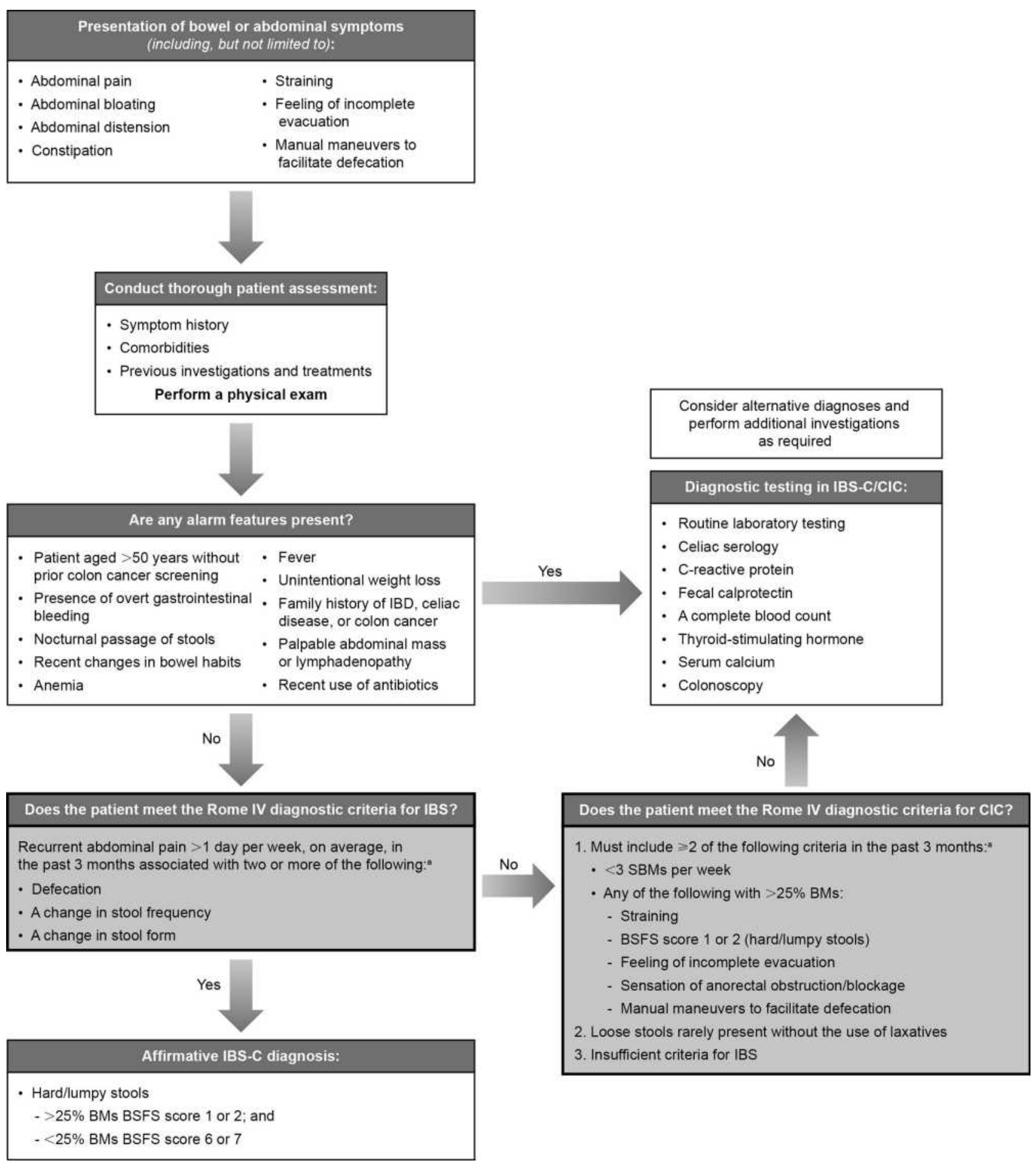

Figure 2 Diagnosing IBS-C and CIC.

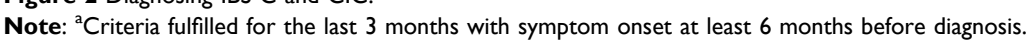

Abbreviations: BM, bowel movement; BSFS, Bristol Stool Form Scale; CIC, chronic idiopathic constipation; IBD, inflammatory bowel disease; IBS, irritable bowel syndrome; IBS-C, irritable bowel syndrome with constipation; SBM, spontaneous bowel movement.

etiologies via the identification of any alarm features. ${ }^{1}$ Alarm features indicating further testing may be required include patients $>50$ years of age without prior colon cancer screening, presence of overt gastrointestinal bleeding, nocturnal passage of stools, unintentional weight loss, a family history of inflammatory bowel disease or colorectal cancer, recent changes in bowel habits, and the presence of a palpable abdominal mass or lymphadenopathy. Additional features prompting further evaluation include anemia, fever, a family history of celiac disease, or recent use of antibiotics. 
If these warning signs are absent, a further patient history should be obtained to quantify the frequency of symptoms and determine whether the patient meets any of the Rome IV diagnostic criteria for disorders of gut-brain interaction. ${ }^{1,3}$ The Bristol Stool Form Scale (BSFS) is a useful tool for evaluating stool consistency in line with Rome criteria. ${ }^{1,22}$ Diagnostic testing for IBS-C and CIC can include limited laboratory tests including specialized testing for alternative etiologies (eg, celiac serology, C-reactive protein, fecal calprotectin), especially if not previously performed. A complete blood count should also be taken, as well as thyroid-stimulating hormone and serum calcium levels assessed where clinically indicated when diagnosing CIC. ${ }^{1}$

\section{IBS-C}

Diagnosis of IBS is made based on clinical history, physical examination, minimal laboratory tests, and other appropriate tests (eg, colonoscopy) as indicated. Diagnosis of IBS requires prior symptom onset of $\geq 6$ months, recurrent abdominal pain occurring $>1$ day per week, on average, over the past 3 months, associated with two or more of defecation, change in stool frequency, or change in stool form. Absence of abdominal pain precludes diagnosis of IBS. IBS-C is defined as $>25 \%$ of BMs with BSFS scores of 1 or 2 (hard/lumpy stool) and $<25 \%$ of BMs with BSFS scores of 6 or 7 (diarrhea/watery stool). Although not required for a diagnosis of IBS, the majority of IBS patients experience abdominal bloating, and abdominal distention may also be reported. ${ }^{1}$ In a study of over 300 patients with IBS-C, abdominal discomfort and bloating were reported as "very or extremely bothersome" by $58 \%$ and $56 \%$ of patients, respectively, ${ }^{2}$ demonstrating the negative impact of these IBS symptoms on patients' lives.

\section{CIC}

Diagnosis of CIC is made based on clinical history, physical examination, minimal laboratory tests as clinically indicated, and specific tests of constipation pathophysiology as required, including anorectal manometry and electromyography; however, these tests are not clinically indicated in all patients. ${ }^{1}$ These tests may be required to identify dyssynergic defecation, which can often overlap with CIC in the same patient. Diagnostic evaluation should only be performed in patients who do not respond to empiric therapy and should be performed while the patient is not taking laxatives. Diagnosis of CIC requires symptom onset $\geq 6$ months before diagnosis and presentation of symptoms during the last 3 months. Abdominal pain, bloating, and distension may be present, but they are not necessarily the predominant symptoms; therefore, individuals with CIC do not fulfill the criteria for IBS. ${ }^{1}$ Diagnostic criteria must include two or more of the following: straining, BMs with BSFS scores 1 or 2, sensation of incomplete evacuation, sensation of anorectal obstruction, a requirement for manual maneuvers for facilitation of defecation for $>25 \%$ of BMs, $<3$ spontaneous BMs per week, loose stools rarely present without the use of laxatives, and insufficient criteria for IBS.

\section{Management of IBS-C and CIC Role of NPs and PAs}

Once a diagnosis is established, the overall aim should be to help patients manage their symptoms and improve their health-related QoL (HRQoL). NPs and PAs are uniquely qualified to establish a positive, communicative, and therapeutic relationship with patients with IBS-C or CIC. ${ }^{23}$ A careful and thorough assessment should be performed, including an evaluation of current symptoms, patient history (including lifestyle, daily habits, activity and exercise levels, food intake and aversions, fluid intake, and sleep habits), and any prior medications and treatment interventions, along with the patient's response to those treatments. $^{1,23}$

\section{Lifestyle and/or Diet Modifications}

Exercise, stress reduction, adequate daily fluid intake, and improved sleep can all help to improve the symptoms of IBS. ${ }^{1}$ Patients with IBS-C or CIC should be educated about eliminating medications that cause or worsen constipation where possible, including opiates, diuretics, and iron or calcium supplements (Table 1). ${ }^{1,9,24}$ A thorough evaluation of patient diet and consultation on maintenance of a routine bathroom schedule should also be discussed. ${ }^{1,25}$

A diet low in fermentable oligo-saccharides, disaccharides, and mono-saccharides and polyols (FODMAPs) may be useful for overall symptom improvement in IBS, ${ }^{26}$ although it is only weakly suggested by current guidelines to treat IBS-C, and is not recommended for treatment of CIC. ${ }^{26,27}$ While evidence suggests that a low FODMAP diet is useful for treating abdominal symptoms in the short term, additional long-term studies are needed. Patients should also be referred to a registered dietitian to assist in nutritional assessment and to provide guidance on dietary modifications. $^{28,29}$ 
Table I Medications Commonly Associated with Constipation

\begin{tabular}{|l|}
\hline - Adrenergic drugs \\
\hline - Analgesics \\
- NSAIDs \\
- Opiates \\
- Tramadol \\
\hline - Anticholinergics \\
\hline - Anticonvulsants \\
\hline - Antihypertensives \\
- Antiarrhythmic agents \\
- Calcium channel blockers \\
- Diuretics \\
- Furosemide \\
- Hydrochlorothiazide \\
\hline - Antiparkinsonian drugs \\
- Dopaminergic agents \\
\hline - Antipsychotics \\
- Phenothiazine derivatives \\
\hline - Bile salt chelators/bile acid binders \\
\hline - Bisphosphonates \\
\hline - Drugs containing cations \\
- Aluminum- or calcium-containing antacids \\
- Bismuth \\
- Calcium supplements \\
- Iron supplements \\
- Lithium \\
\hline - Sucralfate \\
\hline Tricyclic antidepressants \\
\hline Arsmolytics \\
\hline
\end{tabular}

Abbreviation: NSAID, nonsteroidal anti-inflammatory drug.

\section{Over-the-Counter Agents}

The majority of patients with IBS-C and CIC have tried an over-the-counter medication before consulting a healthcare practitioner. ${ }^{19}$ Empiric treatment for IBS-C and CIC should begin with a fiber supplement, followed by osmotic and stimulant laxatives. ${ }^{1}$ In addition, antispasmodics such as peppermint oil are used to treat abdominal pain or cramps, discomfort, and/or bloating associated with IBS, but typically do not improve transit time or stool quality. ${ }^{1,26}$

\section{Fiber}

Soluble fibers such as psyllium or ispaghula husk may provide some symptom relief and improve stool viscosity and frequency in IBS and CIC and remain an evidence-based treatment for IBS. In addition, the low cost and lack of significant side effects make soluble fiber a reasonable firstline therapy. ${ }^{26}$ In patients with CIC, $7 \mathrm{~g}$ of psyllium fiber daily was 3.4 times more effective at increasing stool output and water content than bran cereal alone. ${ }^{30}$ Prunes and prune fiber have also demonstrated efficacy in alleviating constipation, with one meta-analysis demonstrating increased stool frequency and greater improvement in stool consistency compared with the administration of psyllium fiber in patients with constipation or IBS-C. ${ }^{31}$ For CIC, insoluble, nonfermentable fibers increase stool biomass and stool water content and may accelerate transit due to increased stimulation of secretion and motility. Importantly, insoluble fibers such as bran-containing cereals should be limited in IBS as they can exacerbate symptoms such as pain and bloating, and there is no evidence demonstrating efficacy in alleviating symptoms. ${ }^{1,26}$ Total fiber intake of $20-30 \mathrm{~g} /$ day is recommended. ${ }^{1}$

\section{Laxatives}

Osmotic laxatives such as polyethylene glycol and lactulose have demonstrated effectiveness for the treatment of CIC and have improved stool consistency in IBS-C, but have demonstrated little effect on global IBS symptoms, including abdominal pain, compared with placebo (Table 2). ${ }^{1,26,32}$ Stimulant laxatives have demonstrated clinical benefits for stool frequency and other constipation-associated symptoms; however, they are not indicated for chronic use $\mathrm{s}^{33}$ and can induce or worsen abdominal pain symptoms as abdominal pain and cramping are common adverse effects. $^{1,20}$

\section{US Food and Drug Administration-Approved Therapies}

Patients whose symptoms are not adequately controlled by lifestyle changes or over-the-counter agents may require further pharmaceutical intervention. Medication selection is dependent on the patient's most bothersome symptom (constipation, abdominal pain, etc.), response to any prior therapies, as well as patient and provider preference. Prescription medication options include linaclotide, lubiprostone, and plecanatide for both IBS-C and CIC. Tegaserod and tenapanor are approved for the treatment of IBS-C while prucalopride is approved for use in CIC (Table 2). ${ }^{1}$

\section{Non-Approved Medications}

Although not approved by the US Food and Drug Administration, certain prescription medications such as 
Table 2 Overview of Medications Commonly Used in the Management of IBS-C or CIC

\begin{tabular}{|c|c|c|c|c|c|c|}
\hline & MoA & Indication & $\begin{array}{l}\text { Dose and } \\
\text { Administration }\end{array}$ & Efficacy and Safety & Other Considerations & $\begin{array}{l}\text { ACG } \\
\text { Recommendation }{ }^{26,27 a}\end{array}$ \\
\hline \multicolumn{7}{|c|}{ OTC medications } \\
\hline Peppermint oil & $\begin{array}{l}\text { Smooth } \\
\text { muscle } \\
\text { relaxant }\end{array}$ & IBS-C & $\begin{array}{l}\text { I-2 capsules TID } \\
\text { orally, I5-30 min } \\
\text { before food for I } \\
\text { month }^{37}\end{array}$ & $\begin{array}{l}\text { - Improves abdominal pain, } \\
\text { discomfort, and bloating }{ }^{38} \\
\text { - Impact on motility is more } \\
\text { limited }{ }^{38} \\
\text { - Most common AE is } \\
\text { heartburn }\end{array}$ & $\begin{array}{l}\text { - Formulations using novel } \\
\text { coating have been devel- } \\
\text { oped in an attempt to } \\
\text { overcome } \mathrm{AEs}^{38}\end{array}$ & $\begin{array}{l}\text { - Weak recommendation for } \\
\text { overall symptom improve- } \\
\text { ment in IBS based on low- } \\
\text { quality evidence }\end{array}$ \\
\hline $\begin{array}{l}\text { Polyethylene } \\
\text { glycol }\end{array}$ & $\begin{array}{l}\text { Osmotic } \\
\text { laxative }\end{array}$ & $\begin{array}{l}\text { IBS-C } \\
\mathrm{CIC}\end{array}$ & $\begin{array}{l}17 \mathrm{~g} / \text { day, } \\
\text { dissolved in } 8 \mathrm{oz} \\
\text { of water }^{23,39}\end{array}$ & $\begin{array}{l}\text { - Improves stool consistency } \\
\text { and frequency in IBS-C }{ }^{26,38} \\
\text { - No evidence of improvement } \\
\text { in abdominal pain or global } \\
\text { symptoms compared with } \\
\text { PBO }^{26,32,38} \\
\text { - Common AEs include } \\
\text { abdominal pain and } \\
\text { headache }\end{array}$ & $\begin{array}{l}\text { - Not approved for chronic } \\
\text { use }\end{array}$ & $\begin{array}{l}\text { - Weak recommendation for } \\
\text { overall symptom improve- } \\
\text { ment in IBS based on low- } \\
\text { quality evidence } \\
\text { - Strongly recommended for } \\
\text { improving CIC symptoms } \\
\text { based on high-quality } \\
\text { evidence }\end{array}$ \\
\hline \multicolumn{7}{|c|}{ FDA-approved medications } \\
\hline Linaclotide & $\begin{array}{l}\text { GC-C } \\
\text { agonist }\end{array}$ & $\begin{array}{l}\mathrm{IBS}-\mathrm{C} \\
\mathrm{CIC}\end{array}$ & $\begin{array}{l}\text { IBS-C: } 290 \mu \mathrm{g} \\
\text { QD } \\
\text { CIC: } 72 \text { or } 145 \\
\mu g \text { QD } \\
\text { - To be taken on } \\
\text { an empty sto- } \\
\text { mach at least } \\
30 \text { minutes } \\
\text { prior to the } \\
\text { first meal of } \\
\text { the day }{ }^{40}\end{array}$ & $\begin{array}{l}\text { - In IBS-C, significantly more } \\
\text { pts receiving linaclotide met } \\
\text { the primary efficacy end- } \\
\text { points: } \geq 30 \% \text { improvement } \\
\text { in WAP and an increase of } \\
\geq 1 \text { CSBM from baseline } \\
\text { within the same wk ( } \geq 6 / 12 \\
\text { wks of treatment FDA end- } \\
\text { point); or } \geq 3 \text { CSBMs/wk } \\
\text { with an increase of } \geq 1 \\
\text { CSBM from baseline (and } \\
\text { component responses) for } \\
\geq 9 / 12 \text { wks vs PBO }{ }^{41,42} \\
\text { - In CIC, significantly more } \\
\text { pts receiving either dose of } \\
\text { linaclotide achieved the pri- } \\
\text { mary endpoint compared } \\
\text { with PBO ( } \geq 3 \text { CSBMs/wk } \\
\text { and increase of } \geq 1 \text { CSBM } \\
\text { from baseline for } \geq 9 / 12 \\
\text { wks) } \\
\text { - The most common AEs } \\
\text { (reported in } \geq 2 \% \text { of pts } \\
\text { with IBS-C or CIC) are } \\
\text { diarrhea, abdominal pain, } \\
\text { flatulence, and abdominal } \\
\text { distension }{ }^{40}\end{array}$ & $\begin{array}{l}\text { - Contraindicated in pts }<6 \\
\text { years of age and pts with } \\
\text { known or suspected } \\
\text { mechanical Gl obstruction } \\
\text { - Recommended to avoid } \\
\text { linaclotide in pts } 6 \text { to }<18 \\
\text { years of age }\end{array}$ & $\begin{array}{l}\text { - Strongly recommended for } \\
\text { overall symptom improve- } \\
\text { ment in IBS-C based on } \\
\text { high-quality evidence } \\
\text { - Strongly recommended for } \\
\text { treatment of CIC based on } \\
\text { high-quality evidence }\end{array}$ \\
\hline
\end{tabular}


Table 2 (Continued).

\begin{tabular}{|c|c|c|c|c|c|c|}
\hline & MoA & Indication & $\begin{array}{l}\text { Dose and } \\
\text { Administration }\end{array}$ & Efficacy and Safety & Other Considerations & $\begin{array}{l}\text { ACG } \\
\text { Recommendation }{ }^{26,27 a}\end{array}$ \\
\hline Lubiprostone & $\begin{array}{l}\text { Chloride } \\
\text { channel } \\
\text { activator }\end{array}$ & $\begin{array}{l}\text { IBS-C } \\
\text { (females), } \\
\text { CIC }\end{array}$ & $\begin{array}{l}\text { IBS-C: } 8 \mu \mathrm{g} \text { BID } \\
\text { CIC: } 24 \mu \mathrm{g} \text { BID } \\
\text { - To be taken } \\
\text { with food and } \\
\text { water }^{44}\end{array}$ & $\begin{array}{l}\text { - Significantly more pts receiv- } \\
\text { ing lubiprostone were con- } \\
\text { sidered overall responders } \\
\text { (reported moderate relief } 4 \\
\text { wks/month or significant } \\
\text { relief } \geq 2 \text { wks/month [with } \\
\text { no reports of moderate or } \\
\text { severely worse relief] for } \\
\geq 2 / 3 \text { months) compared } \\
\text { with PBO in pts with IBS- } \\
\mathrm{C}^{45} \\
\text { Studies in pts with CIC } \\
\text { demonstrated higher fre- } \\
\text { quency of SBMs across } 4 \\
\text { wks of treatment in lubi- } \\
\text { prostone-treated pts com- } \\
\text { pared with PBO-treated } \\
\text { pts }{ }^{44} \\
\text { The most common AEs } \\
\text { (reported in }>4 \% \text { of pts): } \\
\text { nausea, diarrhea and } \\
\text { abdominal pain for IBS-C pts } \\
\text { and nausea, headache, } \\
\text { abdominal pain, abdominal } \\
\text { distension and flatulence for } \\
\text { CIC pts }{ }^{44}\end{array}$ & $\begin{array}{l}\text { - Contraindicated in pts } \\
\text { with known or suspected } \\
\text { mechanical Gl obstruction } \\
\text { - Approved for use in } \\
\text { female adult pts with IBS- } \\
\text { C; not determined if men } \\
\text { with IBS-C respond } \\
\text { differently }\end{array}$ & $\begin{array}{l}\text { - Strongly recommended for } \\
\text { overall symptom improve- } \\
\text { ment in IBS-C pts based on } \\
\text { moderate-quality evidence } \\
\text { - Strongly recommended for } \\
\text { treatment of CIC based on } \\
\text { high-quality evidence }\end{array}$ \\
\hline Plecanatide & $\begin{array}{l}\text { GC-C } \\
\text { agonist }\end{array}$ & $\begin{array}{l}\text { IBS-C } \\
\mathrm{CIC}\end{array}$ & $\begin{array}{l}3 \mathrm{mg} \text { QD } \\
\text { - To be taken } \\
\text { with or with- } \\
\text { out food }^{46}\end{array}$ & $\begin{array}{l}\text { - In IBS-C, a significantly } \\
\text { greater proportion of pts } \\
\text { receiving plecanatide were } \\
\text { overall responders com- } \\
\text { pared with pts receiving } \\
\text { PBO ( } \geq 30 \% \text { improvement in } \\
\text { WAP and increase in } \geq 1 \\
\text { CSBM/wk from baseline for } \\
\geq 6 / 12 \text { wks) } \\
\text { - } \\
\text { A significantly greater per- } \\
\text { centage of durable overall } \\
\text { CSBM responders was } \\
\text { observed with plecanatide vs } \\
\text { PBO in pts with CIC ( } \geq 3 \\
\text { CSBMs/wk with an increase } \\
\text { of } \geq 1 \text { CSBM/wk from base- } \\
\text { line for } \geq 9 / 12 \text { wks including } \\
\geq 3 \text { of the last } 4 \text { wks) } 48,49 \\
\text { - Diarrhea is the most com- } \\
\text { mon AE (occurring in } \geq 2 \% \\
\text { of pts) })^{46-49}\end{array}$ & $\begin{array}{l}\text { - Contraindicated in pts }<6 \\
\text { years of age and pts with } \\
\text { known or suspected } \\
\text { mechanical Gl obstruction } \\
\text { - Recommended to avoid } \\
\text { plecanatide in pts } 6 \text { to } \\
<18 \text { years of age } 46\end{array}$ & $\begin{array}{l}\text { - Recommended for overall } \\
\text { symptom improvement in } \\
\text { IBS-C based on moderate- } \\
\text { quality evidence }{ }^{b}\end{array}$ \\
\hline
\end{tabular}

(Continued) 
Table 2 (Continued).

\begin{tabular}{|c|c|c|c|c|c|c|}
\hline & MoA & Indication & $\begin{array}{l}\text { Dose and } \\
\text { Administration }\end{array}$ & Efficacy and Safety & Other Considerations & $\begin{array}{l}\text { ACG } \\
\text { Recommendation }{ }^{26,27 a}\end{array}$ \\
\hline Prucalopride & $\begin{array}{l}5-\mathrm{HT}_{4} \\
\text { receptor } \\
\text { agonist }\end{array}$ & $\mathrm{ClC}$ & $\begin{array}{l}2 \mathrm{mg} \text { QD } \\
\text { I mg QD for pts } \\
\text { with severe renal } \\
\text { impairment }^{50}\end{array}$ & $\begin{array}{l}\text { - A significantly greater pro- } \\
\text { portion of pts receiving } \\
\text { prucalopride were respon- } \\
\text { ders vs pts receiving PBO } \\
\text { (responder defined as } \geq 3 \\
\text { CSBMs/wk over } 12 \text { wks) } \\
\text { - The most common AEs } \\
\text { (occurring in } \geq 2 \% \text { of pts): } \\
\text { headache, abdominal pain, } \\
\text { nausea, diarrhea, abdominal } \\
\text { distension, dizziness, vomit- } \\
\text { ing, flatulence, and fatigue }\end{array}$ & $\begin{array}{l}\text { - Contraindicated in pts } \\
\text { with hypersensitivity to } \\
\text { prucalopride or in pts } \\
\text { with intestinal perforation } \\
\text { or obstruction } \\
\text { - Pts should be monitored } \\
\text { for suicidal ideation and } \\
\text { behavior as suicides, sui- } \\
\text { cide attempts, and suicidal } \\
\text { ideation have been } \\
\text { reported }{ }^{50}\end{array}$ & $\begin{array}{l}\text { - Strongly recommended and } \\
\text { determined to be more } \\
\text { effective than PBO in } \\
\text { improving symptoms of } \mathrm{CIC} \\
\text { based on moderate-quality } \\
\text { evidence }^{c}\end{array}$ \\
\hline Tegaserod & $\begin{array}{l}5-\mathrm{HT}_{4} \\
\text { receptor } \\
\text { agonist }\end{array}$ & $\begin{array}{l}\text { IBS-C, } \\
\text { female pts } \\
\text { aged }<65 \\
\text { years }^{\text {d }}\end{array}$ & $\begin{array}{l}6 \mathrm{mg} \text { BID } \geq 30 \\
\text { min before } \\
\text { meals }^{53}\end{array}$ & $\begin{array}{l}\text { - Significantly greater propor- } \\
\text { tions of pts receiving tega- } \\
\text { serod were responders vs } \\
\text { pts receiving PBO (respon- } \\
\text { ders defined as pts reporting } \\
\text { considerable or complete } \\
\text { relief of IBS symptoms } 2 / 4 \\
\text { wks or somewhat relieved } \\
4 / 4 \text { wks) } \\
\text { - Headache, abdominal pain, } \\
\text { nausea, flatulence, dyspep- } \\
\text { sia, and dizziness are the } \\
\text { most common AEs (occur- } \\
\text { ring in } \geq 2 \% \text { of pts) }\end{array}$ & $\begin{array}{l}\text { - Contraindicated in pts } \\
\text { with a history of MI, } \\
\text { stroke, intestinal ischemia, } \\
\text { severe renal impairment, } \\
\text { moderate or severe hepa- } \\
\text { tic impairment, bowel } \\
\text { obstruction, symptomatic } \\
\text { gallbladder disease, sus- } \\
\text { pected SOD, abdominal } \\
\text { adhesions, or hypersensi- } \\
\text { tivity to tegaserod } \\
\text { - Pts should be monitored } \\
\text { for clinical worsening of } \\
\text { depression and emer- } \\
\text { gence of suicidal thoughts } \\
\text { and behaviors }\end{array}$ & - \\
\hline Tenapanor ${ }^{\mathrm{e}}$ & $\begin{array}{l}\text { NHE3 } \\
\text { inhibitor }\end{array}$ & IBS-C & $\begin{array}{l}50 \mathrm{mg}, \mathrm{BID} \\
\text { - To be taken } \\
\text { immediately } \\
\text { prior to the } \\
\text { first and last } \\
\text { meals of } \\
\text { the day }{ }^{54}\end{array}$ & $\begin{array}{l}\text { A significantly greater pro- } \\
\text { portion of pts receiving } \\
\text { tenapanor were primary } \\
\text { responders (defined as } \\
\text { simultaneous } \geq 30 \% \\
\text { improvement in WAP and } \\
\text { increase of } \geq 1 \text { CSBM/wk } \\
\text { from baseline for } 6 / 12 \\
\text { wks) } \\
\text { - The most common AEs } \\
\text { (occurring in } \geq 2 \% \text { of pts) } \\
\text { are diarrhea, abdominal dis- } \\
\text { tension, flatulence, and } \\
\text { dizziness }\end{array}$ & $\begin{array}{l}\text { - Tenapanor is contraindi- } \\
\text { cated in pts }<6 \text { years of } \\
\text { age and pts with known or } \\
\text { suspected mechanical Gl } \\
\text { obstruction } \\
\text { - Recommended to avoid } \\
\text { tenapanor in pts } 6 \text { to }<12 \\
\text { years of age }\end{array}$ & - \\
\hline \multicolumn{7}{|c|}{ Non-FDA-approved prescription medications } \\
\hline Antispasmodics & $\begin{array}{l}\text { Smooth } \\
\text { muscle } \\
\text { relaxant }\end{array}$ & $\begin{array}{l}\text { Not } \\
\text { approved } \\
\text { for use in } \\
\text { IBS or CIC }\end{array}$ & $\begin{array}{l}\text { Hyoscyamine, up } \\
\text { to } 15 \mathrm{mg} / \text { day } \\
\text { Dicyclomine } \\
20-40 \mathrm{mg} \mathrm{QD}{ }^{37}\end{array}$ & $\begin{array}{l}\text { - Can provide short-term } \\
\text { symptom relief } \\
\text { - Effective as a category in IBS, } \\
\text { although evidence support- } \\
\text { ing individual agents is } \\
\text { limited }{ }^{26} \\
\text { - Blurred vision, dizziness, and } \\
\text { dry mouth are common AEs }\end{array}$ & - & $\begin{array}{l}\text { - Weak recommendation for } \\
\text { certain antispasmodics (oti- } \\
\text { lonium, pinaverium, hyos- } \\
\text { cine, cimetropium, } \\
\text { drotaverine, and dicyclo- } \\
\text { mine) for overall symptom } \\
\text { improvement in IBS based } \\
\text { on low-quality evidence }\end{array}$ \\
\hline
\end{tabular}

(Continued) 
Table 2 (Continued).

\begin{tabular}{|c|c|c|c|c|c|c|}
\hline & MoA & Indication & $\begin{array}{l}\text { Dose and } \\
\text { Administration }\end{array}$ & Efficacy and Safety & Other Considerations & $\begin{array}{l}\text { ACG } \\
\text { Recommendation }{ }^{26,27 a}\end{array}$ \\
\hline $\begin{array}{l}\text { SSRIs: } \\
\text { fluoxetine, } \\
\text { paroxetine, } \\
\text { citalopram }\end{array}$ & $\begin{array}{l}\text { Serotonin } \\
\text { reuptake } \\
\text { inhibitor }\end{array}$ & $\begin{array}{l}\text { Not } \\
\text { approved } \\
\text { for use in } \\
\text { IBS or CIC }\end{array}$ & $\begin{array}{l}\text { Fluoxetine: } \\
20 \text { mg QD } \\
\text { Paroxetine: } \\
10-50 \mathrm{mg} \text { QD } \\
\text { Citalopram: } \\
20-40 \mathrm{mg} \mathrm{QD}^{37}\end{array}$ & $\begin{array}{l}\text { - Effective in providing global } \\
\text { symptom relief and improv- } \\
\text { ing pain }{ }^{26,55} \\
\text { - Nausea, insomnia, diarrhea } \\
\text { or constipation, decreased } \\
\text { libido, ejaculatory dysfunc- } \\
\text { tion, and weight gain are } \\
\text { common AEs }{ }^{37} \\
\text { - Use may be limited by AEs } \\
\text { and healthcare provider } \\
\text { acceptance }\end{array}$ & $\begin{array}{l}\text { - Cost of SSRIs may be } \\
\text { a concern for some pts }\end{array}$ & $\begin{array}{l}\text { Weak recommendation for } \\
\text { overall symptom improve- } \\
\text { ment in IBS based on low- } \\
\text { quality evidence }\end{array}$ \\
\hline
\end{tabular}

Notes: aIBS-C recommendations based on the 2018 monograph and $\mathrm{ClC}$ recommendations based on the 2014 monograph; ${ }^{\mathrm{b}} \mathrm{plecanatide}$ was approved for treatment of $\mathrm{CIC}$ subsequent to the publication of the 2014 monograph for $\mathrm{CIC}$; ${ }^{\text {}}$ prucalopride was not available in the US at the time of the 2014 ACG monograph for CIC, but was available in Canada and the European Union; 'tegaserod was withdrawn from the US market in 2007 owing to concerns about cardiovascular AEs and was approved for this specific patient population in March 2019, subsequent to publication of the monograph; ' tenapanor was approved for treatment of IBS-C in September 2019.

Abbreviations: 5- $\mathrm{HT}_{4}$, serotonin-4; ACG, American College of Gastroenterology; AE, adverse event; BID, twice daily; CIC, chronic idiopathic constipation; CSBM, complete spontaneous bowel movement; FDA, US Food and Drug Administration; GC-C, guanylate cyclase-C; GI, gastrointestinal; IBS, irritable bowel syndrome; IBS-C, irritable bowel syndrome with constipation; MI, myocardial infarction; mo, month; MoA, mechanism of action; NHE3, sodium/hydrogen exchanger 3; OTC, over-thecounter; PBO, placebo; pts, patients; QD, once daily; SBM, spontaneous bowel movement; SOD, sphincter of Oddi dysfunction; SSRI, selective serotonin reuptake inhibitor; TID, three times daily; WAP, worst abdominal pain; wk, week.

selective serotonin reuptake inhibitors (SSRIs) and antispasmodics are often used off label (Table 2). SSRIs have demonstrated efficacy in relieving pain and overall symptoms in IBS; however, they are not recommended by the American College of Gastroenterology as the overall evidence is weak. ${ }^{1,26}$ Antispasmodics are sometimes used to treat abdominal cramping, but they should be used with caution as constipation is a common side effect (Table 2 ). ${ }^{26}$

Patients may also seek complementary or alternative medicines, such as herbs, acupuncture, and homeopathy, ${ }^{34,35}$ to treat or supplement the treatment of their condition; however, their efficacy in treating symptoms remains inconclusive and controversial, ${ }^{34,36}$ and these treatments are outside the scope of this review.

\section{Conclusions}

IBS-C and CIC are two disorders of gut-brain interaction, each characterized by a spectrum of bowel and abdominal symptoms, with predominant abdominal pain defining IBS$\mathrm{C}$, and bowel symptoms including straining and feelings of incomplete evacuation defining CIC. These disorders are thought to exist on a continuum of disease severity, and although distinct diagnostic criteria are available for each disorder, it is important to consider each patient's experience over the course of the disorder, as symptom overlap is quite high. Owing to their impact on patient HRQoL and the burden on the healthcare system, reliable diagnosis and effective treatment are critical to the management of these disorders. Management often includes a thorough explanation of the disorder, patient reassurance, and extensive patient counseling. NPs and PAs therefore should feel confident in making a diagnosis of IBS-C or CIC as well as developing individualized management plans for patients based on symptoms. Diet and lifestyle interventions, such as scheduled meals, adequate fluids, increased soluble fiber intake, and exercise, all demonstrate benefit to patients and improvement of symptoms. Some patients may require both lifestyle modifications and pharmaceutical interventions to optimize management of their symptoms.

\section{Acknowledgments}

The authors met the criteria for authorship as recommended by the International Committee of Medical Journal Editors. The authors take full responsibility for the scope, direction, and content of the manuscript and have approved the submitted manuscript. The authors received no compensation related to the development of this manuscript. They would like to thank Katie L. Beski, $\mathrm{PhD}$, and Rebecca Fletcher, BA(Hons), of Complete HealthVizion, Inc., for editorial assistance in the writing and revision of the draft manuscript on the basis of detailed discussion and feedback from all authors; this assistance was funded by Allergan plc (prior to acquisition by AbbVie Inc.) and Ironwood Pharmaceuticals, Inc. 


\section{Funding}

This study was funded by Allergan plc (prior to acquisition by AbbVie Inc.) and Ironwood Pharmaceuticals, Inc.

\section{Disclosure}

Financial arrangements of the authors with companies whose products may be related to the present report are listed as follows: Sarah Patel is a consultant for Allergan plc. Elayne DeSimone is a consultant for Allergan plc. Bethany Doerfler has no conflicts to disclose. Katerine Boutros is an employee of AbbVie Inc. Samson $\mathrm{Ng}$ is a former employee of AbbVie Inc. and owned stock/stock options at the time of employment. Machelle Manuel is a former employee of Ironwood Pharmaceuticals, Inc., and owned stock/stock options at the time of employment. The authors report no other conflicts of interest in this work.

\section{References}

1. Lacy BE, Mearin F, Chang L, et al. Bowel disorders. Gastroenterology. 2016;150(6):1393-1407.e5. doi:10.1053/j. gastro.2016.02.031

2. Heidelbaugh JJ, Stelwagon M, Miller SA, Shea EP, Chey WD. The spectrum of constipation-predominant irritable bowel syndrome and chronic idiopathic constipation: US survey assessing symptoms, care seeking, and disease burden. Am J Gastroenterol. 2015;110 (4):580-587. doi:10.1038/ajg.2015.67

3. Drossman DA. Functional gastrointestinal disorders: history, pathophysiology, clinical features, and Rome IV. Gastroenterology. 2016;150(6):1262-1279. doi:10.1053/j.gastro.2016.02.032

4. Halder SLS, Locke GR, Schleck CD, Zinsmeister AR, Melton LJ, Talley NJ. Natural history of functional gastrointestinal disorders: a 12-year longitudinal population-based study. Gastroenterology. 2007;133(3):799-807. doi:10.1053/j.gastro.2007.06.010

5. Harris LA, Horn J, Kissous-Hunt M, Magnus L, Quigley EMM. The better understanding and recognition of the disconnects, experiences, and needs of patients with chronic idiopathic constipation (BURDEN-CIC) study: results of an online questionnaire. $A d v$ Ther. 2017;34(12):2661-2673. doi:10.1007/s12325-017-0633-5

6. Lacy BE, Moreau JC. Diarrhea-predominant irritable bowel syndrome: diagnosis, etiology, and new treatment considerations. $J$ Am Assoc Nurse Pract. 2016;28(7):393-404. doi:10.1002/2327-6924.12387

7. Vazquez Roque M, Bouras EP. Epidemiology and management of chronic constipation in elderly patients. Clin Interv Aging. 2015;10:919-930. doi:10.2147/CIA.S54304

8. Higgins PDR, Johanson JF. Epidemiology of constipation in North America: a systematic review. Am J Gastroenterol. 2004;99 (4):750-759. doi:10.1111/j.1572-0241.2004.04114.x

9. Bouras EP, Tangalos EG. Chronic constipation in the elderly. Gastroenterol Clin North Am. 2009;38(3):463-480. doi:10.1016/j. gtc.2009.06.001

10. Doshi JA, Cai Q, Buono JL, et al. Economic burden of irritable bowel syndrome with constipation: a retrospective analysis of health care costs in a commercially insured population. J Manag Care Pharm. 2014;20(4):382-390. doi:10.18553/jmcp.2014.20.4.382

11. Saito YA, Schoenfeld P, Locke GR. The epidemiology of irritable bowel syndrome in North America: a systematic review. Am $J$ Gastroenterol. 2002;97(8):1910-1915. doi:10.1111/j.1572-0241. 2002.05913.x
12. Hungin APS, Chang L, Locke GR, Dennis EH, Barghout V. Irritable bowel syndrome in the United States: prevalence, symptom patterns and impact. Aliment Pharmacol Ther. 2005;21(11):1365-1375. doi:10.1111/j.1365-2036.2005.02463.x

13. Choung RS, Locke GR, Schleck CD, Zinsmeister AR, Talley NJ. Cumulative incidence of chronic constipation: a population-based study 1988-2003. Aliment Pharmacol Ther. 2007;26(11-12):1521-1528. doi:10.1111/j.1365-2036.2007.03540.x

14. Canavan C, West J, Card T. The epidemiology of irritable bowel syndrome. Clin Epidemiol. 2014;6:71-80. doi:10.2147/CLEP.S40245

15. Houghton LA, Heitkemper M, Crowell MD, et al. Age, gender, and women's health and the patient. Gastroenterology. 2016;150 (6):1332-1343.e4. doi:10.1053/j.gastro.2016.02.017

16. Nellesen D, Yee K, Chawla A, Lewis BE, Carson RT. A systematic review of the economic and humanistic burden of illness in irritable bowel syndrome and chronic constipation. J Manag Care Pharm. 2013;19(9):755-764. doi:10.18553/jmcp.2013.19.9.755

17. Ruiz-López MC, Coss-Adame E. Quality of life in patients with different constipation subtypes based on the Rome III criteria. Rev Gastroenterol Mex. 2015;80(1):13-20. doi:10.1016/j. rgmx.2015.01.003

18. Johanson JF, Kralstein J. Chronic constipation: a survey of the patient perspective. Aliment Pharmacol Ther. 2007;25(5):599-608. doi:10.1111/j.1365-2036.2006.03238.x

19. American Gastroenterological Association. IBS in America: survey summary findings. 2015. Available from: http://www.multivu.com/ players/English/7634451-aga-ibs-in-america-survey/docs/surveyfindings-pdf-635473172.pdf. Accessed August 24, 2020.

20. Chey WD, Kurlander J, Eswaran S. Irritable bowel syndrome: a clinical review. JAMA. 2015;313(9):949-958. doi:10.1001/ jama.2015.0954

21. Platt FW, Gaspar DL, Coulehan JL, et al. "Tell me about yourself": the patient-centered interview. Ann Intern Med. 2001;134 (11):1079-1085. doi:10.7326/0003-4819-134-11-200106050-00020

22. Lewis SJ, Heaton KW. Stool form scale as a useful guide to intestinal transit time. Scand J Gastroenterol. 1997;32(9):920-924. doi:10.3109/00365529709011203

23. Patel S, DeSimone E, Doerfler BM, Halpert A, Lucak S. Irritable bowel syndrome: practical considerations for nurse practitioners and physician assistants. 2018. Available from: https://www.consul tant360.com/article/gastroenterology/irritable-bowel-syndrome/irrita ble-bowel-syndrome-practical-considerations. Accessed January 21, 2019.

24. Mearin F, Ciriza C, Mínguez M, et al. Clinical practice guideline: irritable bowel syndrome with constipation and functional constipation in the adult. Rev Esp Enferm Dig. 2016;108(6):332-363. doi:10.17235/reed.2016.4389/2016

25. Mounsey A, Raleigh M, Wilson A. Management of constipation in older adults. Am Fam Physician. 2015;92(6):500-504.

26. Ford AC, Moayyedi P, Chey WD, et al. American College of Gastroenterology monograph on management of irritable bowel syndrome. Am $J$ Gastroenterol. 2018;113(Suppl 2):1-18. doi:10.1038/s41395-018-0084-x

27. Ford AC, Moayyedi P, Lacy BE, et al. American College of Gastroenterology monograph on the management of irritable bowel syndrome and chronic idiopathic constipation. Am J Gastroenterol. 2014;109(Suppl 1):S2-S26. doi:10.1038/ajg.2014.187

28. Rao SSC, Yu S, Fedewa A. Systematic review: dietary fibre and FODMAP-restricted diet in the management of constipation and irritable bowel syndrome. Aliment Pharmacol Ther. 2015;41 (12):1256-1270. doi:10.1111/apt.13167

29. Chey WD, Keefer L, Whelan K, Gibson PR. Behavioral and diet therapies in integrated care for patients with irritable bowel syndrome. Gastroenterology. 2021;160(1):47-62. doi:10.1053/j. gastro.2020.06.099 
30. McRorie JW Jr, Fahey GC Jr, Gibb RD, Chey WD. Laxative effects of wheat bran and psyllium: resolving enduring misconceptions about fiber in treatment guidelines for chronic idiopathic constipation. $J \mathrm{Am}$ Assoc Nurse Pract. 2020;32(1):15-23. doi:10.1097/ JXX.0000000000000346

31. Lever E, Cole J, Scott SM, Emery PW, Whelan K. Systematic review: the effect of prunes on gastrointestinal function. Aliment Pharmacol Ther. 2014;40(7):750-758. doi:10.1111/apt.12913

32. Chapman RW, Stanghellini V, Geraint M, Halphen M. Randomized clinical trial: macrogol/PEG 3350 plus electrolytes for treatment of patients with constipation associated with irritable bowel syndrome. Am J Gastroenterol. 2013;108(9):1508-1515. doi:10.1038/ ajg.2013.197

33. Kamm MA, Mueller-Lissner S, Wald A, Richter E, Swallow R, Gessner U. Oral bisacodyl is effective and well-tolerated in patients with chronic constipation. Clin Gastroenterol Hepatol. 2011;9 (7):577-583. doi:10.1016/j.cgh.2011.03.026

34. Chang FY. Irritable bowel syndrome: the evolution of multi-dimensional looking and multidisciplinary treatments. World $J$ Gastroenterol. 2014;20(10):2499-2514. doi:10.3748/wjg.v20. i10.2499

35. Nag A, Martin SA, Mladsi D, Olayinka-Amao O, Purser M, Vekaria RM. The humanistic and economic burden of chronic idiopathic constipation in the USA: a systematic literature review. Clin Exp Gastroenterol. 2020;13:255-265. doi:10.2147/CEG.S239205

36. Peckham EJ, Cooper K, Roberts ER, Agrawal A, Brabyn S, Tew G. Homeopathy for treatment of irritable bowel syndrome. Cochrane Database Syst Rev. 2019;9(9):CD009710. doi:10.1002/14651858. CD009710.pub3

37. Lucak S, Chang L, Halpert A, Harris LA. Current and emergent pharmacologic treatments for irritable bowel syndrome with diarrhea: evidence-based treatment in practice. Therap Adv Gastroenterol. 2017;10(2):253-275. doi:10.1177/1756283X16663396

38. Chey WD. Symposium report: an evidence-based approach to IBS and CIC: applying new advances to daily practice: a review of an adjunct clinical symposium of the American College of Gastroenterology Meeting October 16, 2016, Las Vegas, Nevada. Gastroenterol Hepatol (N.Y.) 2017;13(2 suppl 1):1-16.

39. DiPalma JA, Cleveland MV, McGowan J, Herrera JL. A randomized, multicenter, placebo-controlled trial of polyethylene glycol laxative for chronic treatment of chronic constipation. Am J Gastroenterol. 2007;102(7):1436-1441. doi:10.1111/j.1572-0241.2007.01199.x

40. US Food and Drug Administration. Linzess - highlights of prescribing information. 2020. Available from: https://media.allergan.com/ actavis/actavis/media/allergan-pdf-documents/product-prescribing /Final_labeling_text_10-2018-AR-updates-LINZESS-clean.pdf. Accessed February, 2021.

41. Rao S, Lembo AJ, Shiff SJ, et al. A 12-week, randomized, controlled trial with a 4-week randomized withdrawal period to evaluate the efficacy and safety of linaclotide in irritable bowel syndrome with constipation. Am J Gastroenterol. 2012;107(11):1714-1724. doi:10.1038/ajg.2012.255

42. Chey WD, Lembo AJ, Lavins BJ, et al. Linaclotide for irritable bowel syndrome with constipation: a 26-week, randomized, double-blind, placebo-controlled trial to evaluate efficacy and safety. Am J Gastroenterol. 2012;107(11):1702-1712. doi:10.1038/ ajg.2012.254
43. Lembo AJ, Schneier HA, Shiff SJ, et al. Two randomized trials of linaclotide for chronic constipation. $N$ Engl J Med. 2011;365 (6):527-536. doi:10.1056/NEJMoa1010863

44. US Food and Drug Administration. Amitiza - highlights of prescribing information. 2020. Available from: https://general.takedapharm. com/amitizapi. Accessed February 26, 2021.

45. Drossman DA, Chey WD, Johanson JF, et al. Clinical trial: lubiprostone in patients with constipation-associated irritable bowel syndrome - results of two randomized, placebo-controlled studies. Aliment Pharmacol Ther. 2009;29(3):329-341. doi:10.1111/j.13652036.2008.03881.x

46. US Food and Drug Administration. Trulance - highlights of prescribing information. 2018. Available from: https://www.accessdata.fda.gov/ drugsatfda_docs/label/2018/208745s001lbl.pdf. Accessed August, 2020 .

47. Brenner DM, Fogel R, Dorn SD, et al. Efficacy, safety, and tolerability of plecanatide in patients with irritable bowel syndrome with constipation: results of two phase 3 randomized clinical trials. $\mathrm{Am}$ $J$ Gastroenterol. 2018;113(5):735-745. doi:10.1038/s41395-0180026-7

48. DeMicco M, Barrow L, Hickey B, Shailubhai K, Griffin P. Randomized clinical trial: efficacy and safety of plecanatide in the treatment of chronic idiopathic constipation. Therap $A d v$ Gastroenterol. 2017;10(11):837-851. doi:10.1177/1756283X1773 4697

49. Miner PB Jr, Koltun WD, Wiener GJ, et al. A randomized Phase III clinical trial of plecanatide, a uroguanylin analog, in patients with chronic idiopathic constipation. Am J Gastroenterol. 2017;112 (4):613-621. doi:10.1038/ajg.2016.611

50. US Food and Drug Administration. Prucalopride - highlights of prescribing information. 2018. Available from: https://www.access data.fda.gov/drugsatfda_docs/label/2018/210166s000lbl.pdf. Accessed July 26, 2019.

51. Camilleri M, Kerstens R, Rykx A, Vandeplassche L. A placebo-controlled trial of prucalopride for severe chronic constipation. N Engl J Med. 2008;358(22):2344-2354. doi:10.1056/ NEJMoa0800670

52. Quigley EMM, Vandeplassche L, Kerstens R, Ausma J. Clinical trial: the efficacy, impact on quality of life, and safety and tolerability of prucalopride in severe chronic constipation - a 12-week, randomized, double-blind, placebo-controlled study. Aliment Pharmacol Ther. 2009;29(3):315-328. doi:10.1111/j.1365-2036.2008.03884.x

53. US Food and Drug Administration. Zelnorm - highlights of prescribing information. 2019. Available from: https://www.accessdata.fda. gov/drugsatfda_docs/label/2019/021200Orig1s015lbl.pdf. Accessed April 22, 2019.

54. US Food and Drug Administration. IBSRELA - highlights of prescribing information. 2019. Available from: https://ardelyx.com/wpcontent/uploads/2019/09/PI-Approval.pdf. Accessed December 13, 2019.

55. Ford AC, Talley NJ, Schoenfeld PS, Quigley EMM, Moayyedi P. Efficacy of antidepressants and psychological therapies in irritable bowel syndrome: systematic review and meta-analysis. Gut. 2009;58 (3):367-378. doi:10.1136/gut.2008.163162

56. Drossman DA. Rome IV Functional Gastrointestinal Disorders, Disorders of the Gut-Brain Interaction - Volume II. 4th ed. In: Chang L, Chey WD, Kellow J, Tack J, William E. Whitehead WE, Rome IV Committees, Eds. The Rome Foundation; 2016. 


\section{Publish your work in this journal}

The International Journal of General Medicine is an international, peer-reviewed open-access journal that focuses on general and internal medicine, pathogenesis, epidemiology, diagnosis, monitoring and treatment protocols. The journal is characterized by the rapid reporting of reviews, original research and clinical studies across all disease areas. The manuscript management system is completely online and includes a very quick and fair peer-review system, which is all easy to use. Visit http://www.dovepress.com/ testimonials.php to read real quotes from published authors.

Submit your manuscript here: https://www.dovepress.com/international-journal-of-general-medicine-journal 